\title{
In vitro Efficacy of Non Systemic and Systemic Fungicides against Macrophomina phaseolina causing Charcoal Rot of Soybean
}

\author{
T. Surya Teja ${ }^{1^{*}}$, D. S. Kelayia ${ }^{2}$ and K. Jagadeesha ${ }^{2}$ \\ ${ }^{1}$ Department of Plant Pathology, ${ }^{2}$ Main Oilseeds Research Station, Junagadh Agricultural \\ University, Junagadh, Gujarat, India \\ *Corresponding author
}

\section{A B S T R A C T}

\section{Keywords}

Soybean, Macrophomina phaseolina,

Charcoal rot, Non systemic and systemic fungicides

Article Info

Accepted:

25 September 2020

Available Online:

10 October 2020
Different non systemic and systemic fungicides are tested at four concentrations under in vitro over Macrophomina phaseolina causing charcoal rot of soybean. Among seven non systemic fungicides, mancozeb 75\% WP and propineb 70\% WP were found to be the most effective fungicides with cent per cent mean mycelial inhibition at all concentrations (1000, 1500, 2000 and $2500 \mathrm{ppm})$ tested. While, copper hydroxide 77\% WP and copper oxychloride 50\% WP were found as the least effective with 8.14 and13.09 per cent mean mycelial inhibition, respectively. Among seven systemic fungicides, carbendazim 50\% WP was significantly superior over rest of the treatments with mean mycelial growth inhibition of 82.98 per cent at 100, 250, 500 and 1000 ppm concentrations and fosetyl-Al $80 \%$ WP was found to be the least effective fungicide among all with the mean mycelial inhibition of 44.58 per cent. The sclerotial formation in all agrochemicals was found negatively correlated with the inhibition of growth.

\section{Introduction}

Soybean (Glycine max L.), a legume of commercial importance at both national and global market belongs to family Leguminaceae and sub-family Papilionoideae (Fabaceae). It can enrich the soil with nitrogen because of its $\mathrm{N}$-fixing ability. Soybean is known as the 'golden bean' and 'miracle crop' because it contains about 43 per cent of good quality protein, 21 per cent carbohydrates, 20 per cent oil content, 5 per cent minerals, 8 per cent moisture, 20 per cent fat, 4 per cent fiber and reasonable amounts of vitamins (Gautam et al., 2018).USA, Brazil, Argentina, China, and India contribute about 89 per cent of the total soybean production in the world. In India, soybean oil is used for cooking and soya products are more famous due to the high protein content and also have high export value.

Soybean is subjected to many diseases caused by fungi, bacteria, viruses, mycoplasma and nematodes (Sweets, 2008). Among the different soil borne pathogen of soybean, Macrophomina phaseolina is an important fungus that causes charcoal rot having broad 
host range like soybean, common bean, mung bean, sorghum, maize, cotton, peanut, sesame, cowpea, chickpea and cluster bean producing the symptoms of dry root rot, dry weather wilt, ashy stem blight and seedling blight $(\mathrm{Su}$ et al., 2001). It has also been observed in Saurashtra region of Gujarat specifically during kharif season.

The pathogen causing charcoal rot may infect plants at any developmental stage.At seedling stage, hypocotyls has developed brown lesions (Wegulo et al., 2000).Symptoms of infected plant shown with yellow coloured leaves prior to wilting, reddish brown discolouration of vascular tissues, dark brown to black colour at collar region followed by dried and death of plants. Due to similar symptom of pith tissue discoloration, charcoal rot may be confused with brown stem rot. However, pith tissue discoloration in plants with charcoal rot is limited to the lower part of the soybean stem, often no more than the fifth node, while the discoloration due to brown stem rot can reach higher portion of the stem. In severe cases, the upper one-third of the pods may have flat pods without seeds. Disease and symptom development is optimum under hot and dry weather which favours the disease development.

Impact on economic yield due to charcoal rot of soybean is nearly 35-40 thousand metric tonnes in india (Wrather et al., 2010). To reduce the severity of yield loss and disease incidence, different systemic and non systemic fungicides were tested against Macrophomina phaseolina. Similar research was done by Salunke et al., 2008, Suryawanshi et al., 2008, Dinesh et al., 2017.

\section{Materials and Methods}

\section{Isolationand pathogenicity}

Infected roots of soybean plant showing typical charcoal rot symptom were isolated and followed by multiplication of pathogen by using tissue isolation method. The pathogenicity was proved with artificial inoculation of pathogen stated by Rayatpanah et al., 2012 and Manoj, 2018.

\section{In vitro evaluation of fungicides}

Mycelial growth inhibition under different concentration of non systemic and systemic fungicides were tested against $M$. phaseolina under in vitro condition by employing poisoned food technique of Bagchi and Das (1968) using Potato Dextrose Agar (PDA) as a culture medium. The stock solution of each fungicide has been prepared with 100000 ppm concentration and the required concentration of each fungicide has been taken and mixed with measured quantity of autoclaved PDA medium before solidification in conical flasks respectively with the help of micropipette and then media was poured into sterilized Petri plates $(90 \mathrm{~mm}$ dia.) in equal quantity $(20 \mathrm{ml}$ per Petri plate) to form a uniform layer.

After solidification the plates were inoculated with an actively growing fungal mycelial disc of $4 \mathrm{~mm}$ diameter from the multiplied pure culture plates was transferred under aseptic conditions over the solidified PDA medium. Fungal mycelial disc was inoculated in Petri plates containing PDA medium without fungicides were served as control. Then Petri plates were incubated at $28 \pm 2^{\circ} \mathrm{C}$ for 7 days and observations were recorded based on radial growth of mycelium in treated and control plates. Completely Randomized Block Design with factorial concept was used for analyzing the data. The per cent inhibition of the fungus in each treatment was calculated by using following formula (Vincent, 1947).The relative degree of sclerotial formation was recorded in Table 1.

$\mathrm{I}=\frac{c-T}{c} \times 100$ 
Where,

$\mathrm{I}=$ Percent inhibition of mycelial growth

$\mathrm{C}=$ Radial growth of fungus in control $(\mathrm{mm})$

$\mathrm{T}=$ Radial growth of fungus in treatment $(\mathrm{mm})$

Sclerotial formations were counted in fungal culture suspension under microscope at low power (10x).The fungal culture suspension was prepared by vigorously shaking the $4 \mathrm{~mm}$ mycelial disc of the fungus in $10 \mathrm{ml}$ sterilized distilled water after 15 days of incubation.

\section{Results and Discussion}

The mycelial growth inhibition and sclerotial formation of M. phaseolina causing charcoal rot of soybean was tested with different non systemic and systemic fungicides at various concentrations under in vitro condition were recorded in Table 2 and 3.

The efficacy of seven non-systemic fungicides were tested at various concentrations of 1000, 1500, 2000 and 2500 ppm (Table 2). Among them mancozeb 75\% WP and propineb $70 \%$ WP gave 100 per cent mycelial growth inhibition at all concentrations which were found to superior over the rest of the non systemic fungicides (Fig. 1) followed by Zineb 75\% WP with 79.67 per cent mycelial growth inhibition at $1000 \mathrm{ppm}$ and cent per cent mycelial growth inhibition at1500, 2000 and $2500 \mathrm{ppm}$ concentrations respectively.

More than 70 per cent of mycelial inhibition was observed with thiram $75 \%$ WP at all concentrations tested. While copper hydroxide $77 \%$ WP was found the least effective with 8.14 per cent mean mycelial inhibition.

The production of sclerotia was found to be completely inhibited at all the concentrations tested with mancozeb $75 \% \mathrm{WP}$ and propineb $70 \%$ WP followed by zineb $75 \%$ WP and thiram75\% WP at 1500, 2000 and $2500 \mathrm{ppm}$ concentrations respectively. The abundant sclerotial formation was observed with copper hydroxide 77\% WP and copper oxychloride $50 \% \mathrm{WP}$ at 1000, 1500 and $2000 \mathrm{ppm}$ concentrations.

While chlorothalonil 75\% WP at 1500 and 2000 ppm showed moderate sclerotial formation. Present investigation revealed that mancozeb and propineb which were inhibitory to mycelia could significantly halt the sclerotial formation.

The present results were also found in similar tune with Manoj (2018),Parmaret al., (2017),Suryawanshi et al., (2008) and Salunke et al., (2008).Dinesh et al.(2017) and Magar et al.(2011), where mancozeb was reported to inhibit charcoal rot pathogen at all the concentrations tested.

Table.1 Relative degree of sclerotial formation

\begin{tabular}{|c|l|c|}
\hline No. of sclerotia per microscopic field (10X) & \multicolumn{1}{|c|}{ Grade } & Sign \\
\hline $\mathbf{0}$ & Absent & - \\
\hline $1-4$ & Scanty & + \\
\hline $\mathbf{5 - 8}$ & Moderate & ++ \\
\hline $\mathbf{9 - 1 5}$ & Good & +++ \\
\hline$>15$ & Abundant & ++++ \\
\hline
\end{tabular}


Table.2 Effect of different systemic fungicides on mycelial growth inhibition and sclerotial formation of $M$. phaseolinaunder in vitro condition

\begin{tabular}{|c|c|c|c|c|c|}
\hline \multirow[t]{2}{*}{ Fungicides } & \multicolumn{4}{|c|}{$\begin{array}{l}\text { Concentration (ppm) and } \\
\text { Sclerotial formation }\end{array}$} & \multirow{2}{*}{$\begin{array}{c}\text { Mean fungicide } \\
\text { inhibition } \\
(\%)\end{array}$} \\
\hline & 1000 & 1500 & 2000 & 2500 & \\
\hline \multirow[t]{2}{*}{$\begin{array}{l}\text { Chlorothalonil } \\
75 \% \text { WP }\end{array}$} & $\begin{array}{c}43.30 \\
(47.04)\end{array}$ & $\begin{array}{c}45.11 \\
(50.18)\end{array}$ & $\begin{array}{c}47.90 \\
(55.05)\end{array}$ & $\begin{array}{c}50.83 \\
(60.11)\end{array}$ & \multirow[t]{2}{*}{$\begin{array}{c}46.79 \\
(53.11)\end{array}$} \\
\hline & +++ & ++ & ++ & + & \\
\hline \multirow[t]{2}{*}{$\begin{array}{l}\text { Copper hydroxide } \\
77 \% \text { WP }\end{array}$} & $\begin{array}{l}12.00 \\
(4.32)\end{array}$ & $\begin{array}{l}16.90 \\
(8.45)\end{array}$ & $\begin{array}{l}18.02 \\
(9.57)\end{array}$ & $\begin{array}{c}19.40 \\
(11.03)\end{array}$ & \multirow[t]{2}{*}{$\begin{array}{l}16.58 \\
(8.14)\end{array}$} \\
\hline & ++++ & ++++ & ++++ & +++ & \\
\hline \multirow[t]{2}{*}{$\begin{array}{l}\text { Copper oxychloride } \\
50 \% \text { WP }\end{array}$} & $\begin{array}{l}17.45 \\
(8.99)\end{array}$ & $\begin{array}{c}20.14 \\
(11.85)\end{array}$ & $\begin{array}{c}22.45 \\
(14.58)\end{array}$ & $\begin{array}{c}24.81 \\
(17.60)\end{array}$ & \multirow[t]{2}{*}{$\begin{array}{c}21.21 \\
(13.09)\end{array}$} \\
\hline & ++++ & ++++ & ++++ & +++ & \\
\hline \multirow[t]{2}{*}{ Mancozeb 75\% WP } & $\begin{array}{c}90.00 \\
(100.00)\end{array}$ & $\begin{array}{c}90.00 \\
(100.00)\end{array}$ & $\begin{array}{c}90.00 \\
(100.00)\end{array}$ & $\begin{array}{c}90.00 \\
(100.00)\end{array}$ & \multirow[t]{2}{*}{$\begin{array}{c}90.00 \\
(100.00)\end{array}$} \\
\hline & - & - & - & - & \\
\hline \multirow[t]{2}{*}{ Propineb 70\% WP } & $\begin{array}{c}90.00 \\
(100.00)\end{array}$ & $\begin{array}{c}90.00 \\
(100.00)\end{array}$ & $\begin{array}{c}90.00 \\
(100.00)\end{array}$ & $\begin{array}{c}90.00 \\
(100.00)\end{array}$ & \multirow[t]{2}{*}{$\begin{array}{c}90.00 \\
(100.00)\end{array}$} \\
\hline & - & - & - & - & \\
\hline \multirow[t]{2}{*}{ Thiram $75 \%$ WP } & $\begin{array}{c}60.62 \\
(75.93)\end{array}$ & $\begin{array}{c}63.48 \\
(80.06)\end{array}$ & $\begin{array}{c}65.23 \\
(82.44)\end{array}$ & $\begin{array}{c}67.56 \\
(85.43)\end{array}$ & \multirow[t]{2}{*}{$\begin{array}{c}64.22 \\
(81.09)\end{array}$} \\
\hline & + & - & - & - & \\
\hline \multirow[t]{2}{*}{ Zineb $75 \% W P$} & $\begin{array}{c}63.20 \\
(79.67)\end{array}$ & $\begin{array}{c}90.00 \\
(100.00)\end{array}$ & $\begin{array}{c}90.00 \\
(100.00)\end{array}$ & $\begin{array}{c}90.00 \\
(100.00)\end{array}$ & \multirow[t]{2}{*}{$\begin{array}{c}83.30 \\
(98.64)\end{array}$} \\
\hline & + & - & - & - & \\
\hline \multirow[t]{2}{*}{$\begin{array}{r}\text { Concentration } \\
\text { Mean (\%) }\end{array}$} & $\begin{array}{c}53.80 \\
(65.11)\end{array}$ & $\begin{array}{c}59.37 \\
(74.05)\end{array}$ & $\begin{array}{c}60.52 \\
(75.77)\end{array}$ & $\begin{array}{c}61.80 \\
(77.67)\end{array}$ & \\
\hline & $\begin{array}{l}\text { Fungicide } \\
\text { (F) }\end{array}$ & Conc. (C) & \multicolumn{3}{|c|}{ F $\times C$} \\
\hline S.Em. \pm & 0.65 & 0.49 & \multicolumn{3}{|c|}{1.29} \\
\hline C. D. at $5 \%$ & 1.84 & 1.39 & \multicolumn{3}{|c|}{3.68} \\
\hline C.V. \% & \multicolumn{5}{|c|}{3.82} \\
\hline
\end{tabular}

Data were arcsine transformed before analysis; Numerals in parentheses are re-transformed value 
Table.3 Effect of different systemic fungicides on mycelial growth inhibition and sclerotial formation of M. phaseolina under in vitro condition

\begin{tabular}{|c|c|c|c|c|c|}
\hline \multirow[t]{2}{*}{ Fungicides } & \multicolumn{4}{|c|}{$\begin{array}{l}\text { Concentration (ppm) and } \\
\text { Sclerotial formation }\end{array}$} & \multirow{2}{*}{$\begin{array}{c}\text { Mean fungicide } \\
\text { inhibition } \\
(\%)\end{array}$} \\
\hline & 100 & 250 & 500 & 1000 & \\
\hline \multirow[t]{2}{*}{$\begin{array}{l}\text { Difenoconazole } 25 \% \\
\text { EC }\end{array}$} & $\begin{array}{c}53.39 \\
(64.43)\end{array}$ & $\begin{array}{c}56.14 \\
(68.95)\end{array}$ & $\begin{array}{c}59.12 \\
(73.66)\end{array}$ & $\begin{array}{c}61.94 \\
(77.88)\end{array}$ & \multirow[t]{2}{*}{$\begin{array}{c}57.65 \\
(71.36)\end{array}$} \\
\hline & ++ & + & - & - & \\
\hline \multirow[t]{2}{*}{$\begin{array}{l}\text { Carbendazim 50\% } \\
\text { WP }\end{array}$} & $\begin{array}{c}57.59 \\
(71.27)\end{array}$ & $\begin{array}{c}61.03 \\
(76.54)\end{array}$ & $\begin{array}{c}68.92 \\
(87.06)\end{array}$ & $\begin{array}{c}75.02 \\
(93.31)\end{array}$ & \multirow[t]{2}{*}{$\begin{array}{c}65.64 \\
(82.98)\end{array}$} \\
\hline & - & - & - & - & \\
\hline \multirow[t]{2}{*}{ Fosetyl-Al 80\% WP } & $\begin{array}{c}32.47 \\
(28.82)\end{array}$ & $\begin{array}{c}37.47 \\
(37.00)\end{array}$ & $\begin{array}{c}45.21 \\
(50.37)\end{array}$ & $\begin{array}{c}52.41 \\
(62.79)\end{array}$ & \multirow[t]{2}{*}{$\begin{array}{c}41.89 \\
(44.58)\end{array}$} \\
\hline & +++ & +++ & ++ & + & \\
\hline \multirow[t]{2}{*}{$\begin{array}{l}\text { Azoxystrobin } 23 \% \\
\text { SC }\end{array}$} & $\begin{array}{c}27.98 \\
(22.01)\end{array}$ & $\begin{array}{c}44.68 \\
(49.44)\end{array}$ & $\begin{array}{c}51.54 \\
(61.32)\end{array}$ & $\begin{array}{c}56.22 \\
(69.08)\end{array}$ & \multirow[t]{2}{*}{$\begin{array}{c}45.11 \\
(50.18)\end{array}$} \\
\hline & +++ & ++ & + & - & \\
\hline \multirow[t]{2}{*}{$\begin{array}{l}\text { Picoxystrobin } 25 \% \\
\text { EC }\end{array}$} & $\begin{array}{c}53.07 \\
(63.89)\end{array}$ & $\begin{array}{c}56.43 \\
(69.42)\end{array}$ & $\begin{array}{c}63.72 \\
(80.40)\end{array}$ & $\begin{array}{c}67.60 \\
(85.48)\end{array}$ & \multirow[t]{2}{*}{$\begin{array}{c}60.21 \\
(75.31)\end{array}$} \\
\hline & ++ & + & - & - & \\
\hline \multirow[t]{2}{*}{ Tebuconazole $2 \%$ DS } & $\begin{array}{c}45.21 \\
(50.37)\end{array}$ & $\begin{array}{c}52.94 \\
(63.67)\end{array}$ & $\begin{array}{c}61.88 \\
(77.78)\end{array}$ & $\begin{array}{c}66.66 \\
(84.31)\end{array}$ & \multirow[t]{2}{*}{$\begin{array}{c}56.67 \\
(69.81)\end{array}$} \\
\hline & ++ & + & - & - & \\
\hline \multirow[t]{2}{*}{$\begin{array}{l}\text { Thiophanate methyl } \\
\text { 70\% WP }\end{array}$} & $\begin{array}{c}45.85 \\
(51.48)\end{array}$ & $\begin{array}{c}52.54 \\
(63.01)\end{array}$ & $\begin{array}{c}59.78 \\
(74.66)\end{array}$ & $\begin{array}{c}63.97 \\
(80.74)\end{array}$ & \multirow[t]{2}{*}{$\begin{array}{c}55.53 \\
(67.97)\end{array}$} \\
\hline & ++ & + & - & - & \\
\hline \multirow[t]{2}{*}{$\begin{array}{c}\text { Concentration } \\
\text { Mean (\%) }\end{array}$} & $\begin{array}{c}45.08 \\
(50.14)\end{array}$ & $\begin{array}{c}51.60 \\
(61.42)\end{array}$ & $\begin{array}{c}58.60 \\
(72.85)\end{array}$ & $\begin{array}{c}63.40 \\
(79.96)\end{array}$ & \\
\hline & $\begin{array}{l}\text { Fungicide } \\
\text { (F) }\end{array}$ & Conc. (C) & \multicolumn{3}{|c|}{$\mathbf{F} \times \mathbf{C}$} \\
\hline S.Em. \pm & 0.60 & 0.46 & \multicolumn{3}{|c|}{1.21} \\
\hline C. D. at $5 \%$ & 1.71 & 1.29 & \multicolumn{3}{|c|}{3.42} \\
\hline C.V. \% & \multicolumn{5}{|c|}{3.83} \\
\hline
\end{tabular}

Data were arcsine transformed before analysis; Numerals in parentheses are re-transformed value 
Fig.1 Non-systemic fungicides on mycelial growth inhibition of M. phaseolina under in vitro

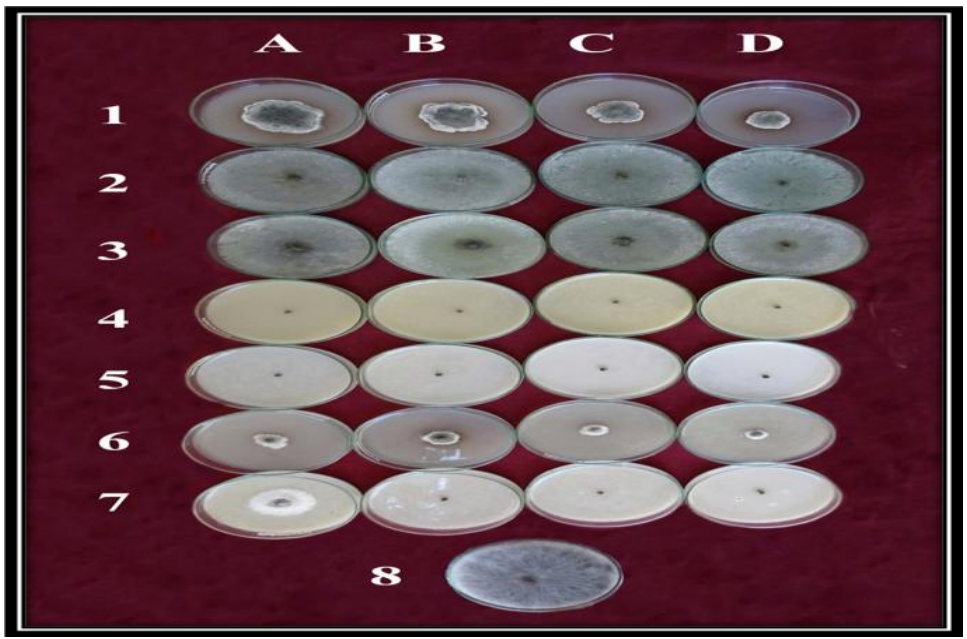

Non-systemic fungicides Concentrations (ppm)

1. Chlorothalonil $75 \%$ WP A. 1000

2. Copper hydroxide $77 \%$ WP B. 1500

3. Copper oxychloride $50 \%$ WP C. 2000

4. Mancozeb $75 \%$ WP D. 2500

5. Propineb $70 \% \mathrm{WP}$

6. Thiram $75 \% \mathrm{WP}$

7. Zineb $75 \% \mathrm{WP}$

Fig.2 Systemic fungicides on mycelial growth inhibition of $M$. phaseolina under in vitro

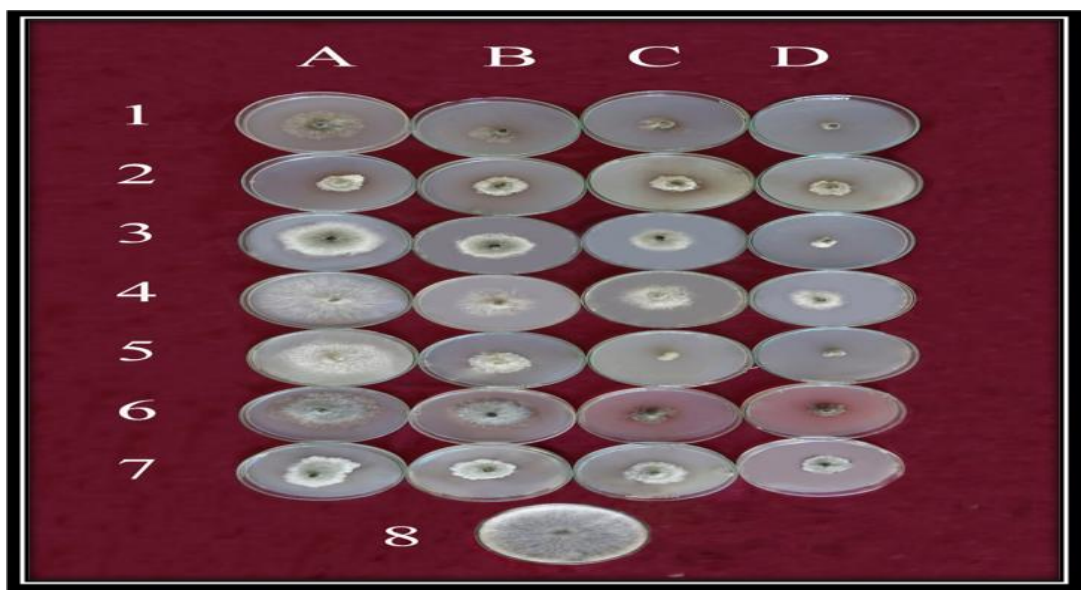

Systemic fungicides Concentrations (ppm)

1. Difenoconazole $25 \%$ EC A. 100

2. Carbendazim 50\% WP B. 250

3. Fosetyl-Al 80\% WP C. 500

4. Azoxystrobin $23 \%$ SC D. 1000

5. Picoxystrobin $25 \%$ EC

6. Tebuconazole $2 \%$ DS

7. Thiophanate methyl $70 \%$ WP 
Graph.1 Effect of non-systemic fungicides on mycelial growth inhibition of $M$. phaseolina under in vitro condition

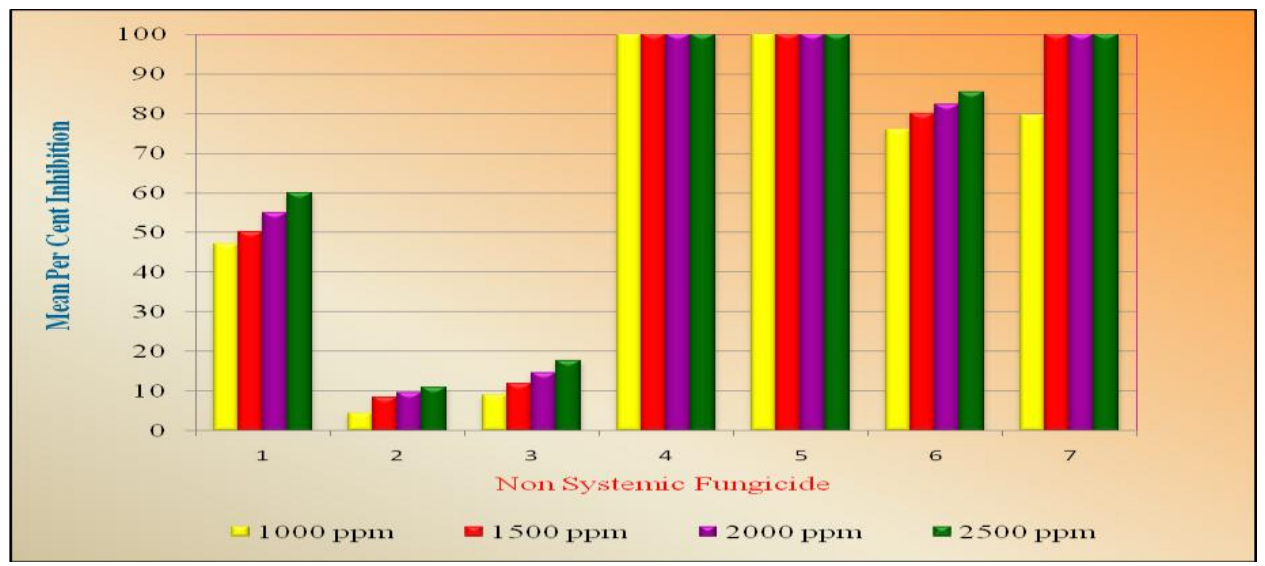

1. Chlorothalonil $75 \% \mathrm{WP}$

2. Copper hydroxide $77 \% \mathrm{WP}$

3. Copper oxychloride $50 \% \mathrm{WP}$

4. Mancozeb $75 \%$ WP

5. Propineb $70 \%$ WP

6. Thiram $75 \% \mathrm{WP}$

7. Zineb $75 \% \mathrm{WP}$

Graph.2 Effect of systemic fungicides on mycelial growth inhibition of M. phaseolina under in vitro condition

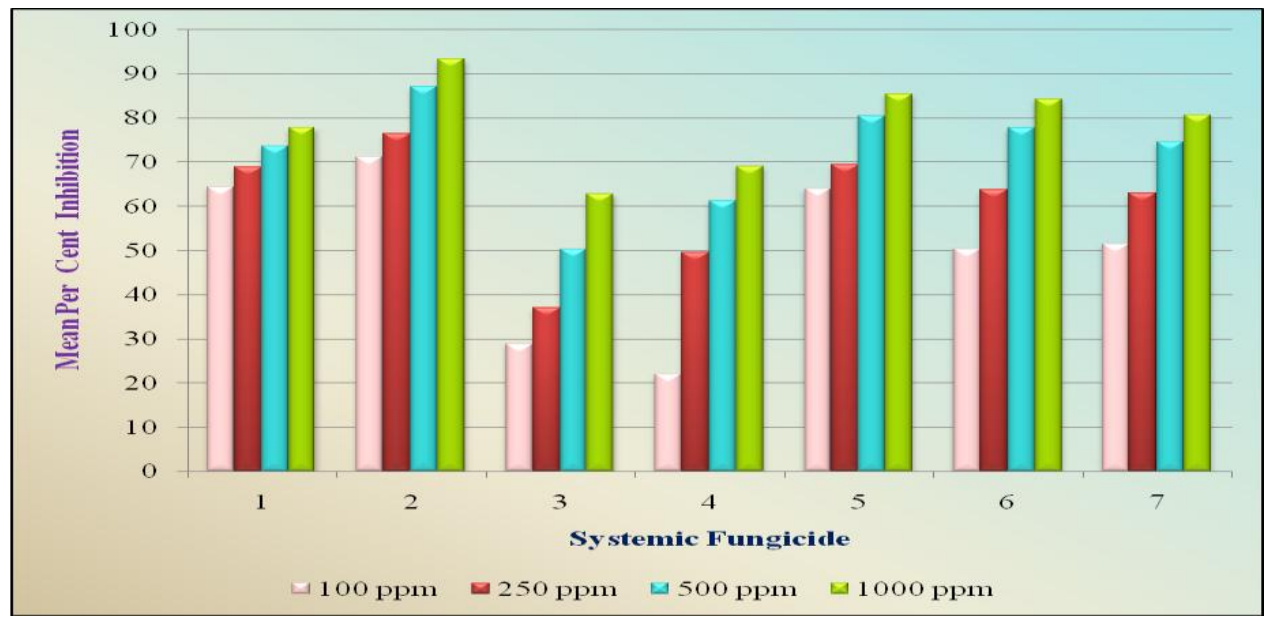

1. Difenoconazole $25 \% \mathrm{EC}$

2. Carbendazim 50\% WP

3. Fosetyl-Al $80 \%$ WP

4. Azoxystrobin $23 \%$ SC

5. Picoxystrobin $25 \%$ EC

6. Tebuconazole $2 \%$ DS

7. Thiophanate methyl $70 \% \mathrm{WP}$ 
Similarily among seven systemic fungicides (Table 3), carbendazim 50\% WP found to be best among all treatments and gave 71.27, 76.54, 87.06 and 93.31per cent inhibition of growth of the fungus at all concentrations (100, 250, 500 and $1000 \mathrm{ppm})$ respectively as shown in Fig. 2.Picoxystrobin 25\% EC (500 and $1000 \mathrm{ppm}$ ), tebuconazole 2\% DS (1000 ppm) and thiophanate methyl 70\% WP (1000 ppm) were shown more than 80 per cent mycelial growth inhibition. Fosetyl-Al $80 \%$ WP was found as least effective fungicide with28.82, 37.00, 50.37 and 62.79 per cent at 100, 250, 500 and 1000 ppm concentrations respectively.

No sclerotial formation was observed at all the tested concentrations of carbendazim $50 \%$ WP and for all the treatments at 500 and 1000 ppmexcept with fosetyl-Al $80 \% \mathrm{WP}$ and azoxystrobin $23 \% \mathrm{SC}$ at $500 \mathrm{ppm}$. However, fosetyl-Al $80 \% \mathrm{WP}$ at 100 and $250 \mathrm{ppm}$ and azoxystrobin $23 \%$ SCat 100 ppm exhibited good sclerotial production.

The results obtained were in agreement with Iqbal and Mukhtar (2020), Ashish and Gohel (2018), Swamyet al., (2018), Dinesh et al., (2017), Arora et al., (2013), Suryawanshi et al., (2008) and Lambhate et al., (2002) who evaluated the efficacy of carbendazim on $M$. phaseolina of various crops.

In conclusion the present study revealed thatmancozeb and propineb from non systemic as well as carbendazim from systemic fungicides were quite effective in controlling soybean charcoal rot pathogen.

Along with physical, cultural and biological practices, use of chemical measures with these effective fungicides in alternate application will give better result and will reduce the risk of resistance development in the pathogen.

\section{References}

Arora, M.; Indore, S.; Dhurwe, U. and Malwa, S. (2013). Chemical control of charcoal rots of sorghum, caused by $M$. phaseolina (Goid). South Pacific Journal of PharmaBioScience. 1: 12-16.

Ashish, K. S. and Gohel, N.M. (2018). Evaluation of antagonistic potential of biocontrol agents against Macrophomina phaseolina (tassi) Goid. causing stem and root rot of sesame [Sesamumindicum L.] under in vitro and in vivo. International Journal of Current Microbiology and Applied Sciences. 7(12): 1748-1754.

Bagchi, B.N. and Das, C. R.(1968). Studies on the biological spectrum and sensitivity of some fungicides. Indian Phytopathology.21: 397-400.

Dinesh, H.; Chaudhary, D.; Pathak, M. and Mahesh, M. (2017). In vitro efficacy of fungicides against dry root rot $(M$. phaseolina) of soybean. International Journal of Current Microbiology and Applied Sciences. 6(8): 1298-1301.

Gautam, D.; Kumar, A.; Prakash, A. and Pandey, D. C. (2018). An economic efficiency of soybean production in Malwa region of Madhya Pradesh. International Journal of Chemical Studies. 6(2): 636-639.

Iqbal, U. and Mukhtar, T. (2020). Inhibitory effects of some fungicides against Macrophomina phaseolina causing charcoal rot. Pakistan Journal of Zoology. 52(2): 709-715.

Lambhate, S. S.; Chaudhari, G. K.; Mehetre, S. S. and Zanjare, S. R. (2002). In vitro evaluations of chemicals against root rot of cotton caused by $M$. phaseolina. Journal of Maharashtra Agricultural University. 27(1): 99100.

Magar, S. V.; Kadam, J. J.; Rite, S. C.; 
Thaware, D. S. and Potphode, P. D. (2011). Exploration of plant extracts and fungal antagonists against Macrophomina phaseolina (Tassi.) Goid. causing leaf spot in greengram. International Journal of Plant Protection. 4(1): 30-33.

Manoj, K. B. (2018). Root rot of groundnut (Arachishypogaea L.) caused by Macrophomina phaseolina(Tassi) Goid and its management. M.Sc. (Agri.)Thesis. Junagadh Agricultural University, Junagadh.

Parmar, H. V.; Kapadiya, H. J. and Bhaliya, C. M. (2017). Efficacy of different fungicides against Macrophomina phaseolina (Tassi) Goid causing castor root rot. International Journal of Chemical Studies. 5(5): 1807-1809.

Rayatpanah, S.; Nanagulyan, S. G.; Alav, S. V.; Razavi, M. and Malidarreh, A. G. (2012). Pathogenic and genetic diversity among iranian isolates of Macrophomina phaseolina. Chilean Journal of Agricultural Research. 72(1): 40-44.

Salunke, V. N.; Sarita, A and Ingle, R. W. (2008). Efficacy of fungicides and antagonistic effect of bioagent against Rhizoctonia bataticola isolates. Annals of Plant Physiology. 22(1): 134-137.

Su, G.; Suh, S. O.; Schneider, R. W. and Russin, J. S. 2001. Host specialization in the charcoal rot fungus, Macrophomina phaseolina.
Phytopathology. 91(2): 120-126.

Suryawanshi, A.; Gore, P. D. D.; Gawade, D. B.; Pawar, A. K. and Wadje, A. G. (2008). Efficiency of fungicides against Macrophomina blight of mungbean. Journal of Plant Disease Science. 3(1): 40-42.

Swamy, C.; Naik, M. K.; Amaresh, Y. S. and Jayalakshmi, S. K. (2018). Evaluation of fungicides and bio-agents under in vitro condition against Macrophomina phaseolina causing stem canker of pigeon pea. International Journal of Current Microbiology and Applied Sciences. 7(1): 811-819.

Sweets, L. (2008). Early season soybean diseases. Integrated Pest Crop Management. 18(12): 82.

Vincent, J. M. (1947). Distortion of fungal hyphae in the presence of certain inhibitors. Nature. 159(4051): 850851.

Wegulo, S. N.; Sun, P.; Martinson, C.A. and Yang, X. B.(2000). Spread of Sclerotinia stem rot of soybean from area and point sources of apothecial inoculum. Canadian journal of plant science.80(2): 389-402.

Wrather, A.; Shannon, G.; Balardin, R.; Carregal, L.; Escobar, R.; Gupta, G. K.; Ma, Z.; Morel, W.; Ploper, D.; and Tenuta, A. (2010). Effect of diseases on soybean yield in the top eight producing countries in 2006. Plant Health Progress. 10:1094.

\section{How to cite this article:}

Surya Teja, T., D. S. Kelayia and Jagadeesha, K. 2020. In vitro Efficacy of Non Systemic and Systemic Fungicides against Macrophomina phaseolina causing Charcoal Rot of Soybean. Int.J.Curr.Microbiol.App.Sci. 9(10): 3791-3799. doi: https://doi.org/10.20546/ijcmas.2020.910.436 